\title{
Impacts of 9/11 on Smaller States of South Asia. Written By: Khalid Mahmood Faisal, Mohammad ,Iqbal Khan Impact of 9/11 on the smaller states of South Asia
}

\author{
Khalid Mahmood Faisal, Mohammad Iqbal Khan \\ P.h.D. Research Scholar (Political Science) The Islamia University Bahawalpur. \\ P.h.D. Research Scholar (Islamic Studies) Bahauddin Zakariya University Multan.
}

\begin{abstract}
The 9/11 events had a profound impact on security dynamics of South Asia. When the US lead collation search for Osama Bin Laden was being conducted in Afghanistan. Pakistan as the neighbor of Afghanistan naturally suffered along with the smaller states of South Asia in the multi dimension ways impacting the ongoing insurgencies fight for the self determination struggle for autonomy their economies, trade, foreign investment and their perception towards United States Terrorism and its political consequences have directly and visibly effected interstates relations in South Asia and have also led to destabilization in the region.
\end{abstract}

In the last few years the Soviet Union has disintegrated, the cold war has ended, and the structure of the international political system has shifted from bipolarity to uni-polarity. Now, the quest for peace and justice is perhaps a core issue and a major shared aspiration in most of the world region. In the post-world wars era, a functional approach of trade, travel, and democracy was considered as a basis for internationalism. In an era of search for peace, efforts were made to avoid physical wars, considered enemy of free trade and travel. The age of cold war offered new opportunities for developments of regional economics, mutual understanding, and nuclear deterrence. Emergence of the institutions of United Nations, theoretical, was materialization of pacifism at a global international level. Leaving aside the success or failure of this international body, its major role was supposed to be facilitation of peaceful resolution of conflicts. The whole security system has changed after the incidents of $9 / 11$. What the international community had achieved in the democratic struggle of 200years has now been imperiled. Nations of the world are worried about the status and the role of the United Nations. "The very basis of the international law is being shaken, it's settled norms and principles are being questioned. The sovereign and independent nations are being ensnared in different traps: law principles and norms are all being trampled in the name of war against terrorism. The trend of pushing with out proving the crime is gaining in strength; the Nations and countries are being invaded under pretext of shaky reasons and perceived threats or for such objective as regime change. $" 1$

The 9/11 terrorist attack in America posed severe psychological and security challenges to the United States administration. Initially it was extremely difficult to take any major decision as the country was passing through immense insecurity crises. The whole World condemned these acts of terrorism and pledged their support to the US for any possible action against the terrorists and their hideouts. Pakistan, being victim of religious and sectarian terrorism itself for the last many years due to the Afghan crisis, also condemned the terrorist attacks and promised to join the International community to wipe out terrorism. For this purpose President Mr. Bush announced on September 20,2001 that "Every nation in every Region now has a decision to make, either you are with us or with the terrorists" 2

The terrorist attacks in New York, Washington and Pennsylvania on september11, 2001, left a profound impact not only within the United States of America but also on the international security environment. The US Secretary of state, Colin Powel emphasized this point in one of his press briefing that people of about 60 countries have died in the New York. Therefore, almost the entire international community committed to side with the US war on terror. Therefore, almost the entire international community committed to side with the US on war on terror. When George W. Bush became the newest President of the white house in January 2001, his Republican Administration continued the Clinton policy of engagement in South Asia, with the special emphasis on US -India relations. The terrorist attack in New York and Washington, however, changed US agenda in South Asia dramatically as the united States for the first time found itself in the un accustomed position of having good relations with India and Pakistan; India offered its full support for US

\footnotetext{
${ }^{1}$ Ahmed Khurshid Prof: (Feb. 2004) Presidential Address and challenges to Pakistan, Tarjman-ul-Quran Lahore P. 12

${ }^{2}$ Hussain Nazar (2003) War on terrorism; implication for Pakistan, Al-Siyasa-A journal of politics, society \& culture, University of Punjab, Lahore. P. 39
} 
counter terrorism efforts and Pakistan decided to align itself with the US. The attack on the world trade centre and Pentagon turned US South Asian policy temporarily upside down, bringing Pakistan to centre stage and putting parts of the United States -India agenda on hold the search for Bin laden and the war against international terrorism was initiated and conducted in Afghanistan, therefore, the impact of the tremors created by the bombing in Afghanistan and fight against terrorism were immediately felt in the South Asia region. Pakistan being the neighbor and supporter of Taliban regime in Afghanistan an ally of the US war against the Soviet invasion of Afghanistan in the past, was supposed to play an important role in any US action in Afghanistan. "By supporting the US, Pakistan had to reverse its own Afghan policy and earn the wrath of domestic public opinion" ${ }^{3}$

As the president Musharraf admitted that Pakistan is facing a very critical situation and I believe that after 1971, this is most critical period. "The decision we take today can have far reaching and wide- ranging consequences. The crises are extremely strong and wide- spread. If we take the wrong decision in these crises, it can lead to the worst possible consequences. The negative consequence can in danger Pakistan's integrity and solidarity. I mean our strategic assets and the cause of Kashmir. If these come under threat, it would be a worst situation for us" ${ }^{4}$

A personal letter from Musharraf to Mullah Umar advising him to understand the seriousness of the present situation did not make a difference. After $9 / 11$, co-relationships of forces changed. General Musharraf decided to make a U-turn in Pakistan policy towards Afghanistan and agreed to provide UN stinted support to the United States in its efforts to eliminate the scourge of international terrorism. Musharraf accepted all the seven requests made by the US. He agreed to allow Pakistan's air space to be used by the US air force. Three air bases were provided to be used by the American air force for logistic support "Musharraf immediately response, accepting all the US requests, was criticized by the section of population" 5

The Taliban regime in Afghanistan had the regional agenda for its activities which infuriated the regional friends of Pakistan especially China and Iran. The US designed to permanently station their troops in Afghanistan and central Asia were indirect conflict with the security interest of China and Pakistan .The Chinese access and financial support for the Gawadar Port was also of serious concern to the Us although Pakistan is able to restore its confidence to China but it could not do so with Iran .A more serious regional implication which Pakistan had to suffer was the reversal of its foreign policy. It would be more accurate if we say that the international system at some levels was already under a gradual transformation since the end of cold war many efforts were made to redefine the nature of international system of the demise of the USSR. With the regards to its former cold war adversary, Russia, it is ironic that after the terrorist attacks "President Vildamir Putin was the first world leader to contact President Bush and covey strong support. Russia's contribution to the fight against the international terrorism has been critical and substantial including securing the cooperation of the Central Asian Republics for US military operations opening Russian air space for US humanitarian and support flights, and close consultation and sharing the Russian intelligence." ${ }^{.6}$ As the reflection of this new partnership have also announced to slash US and Russian nuclear arsenals by two thirds with in decade, thus ridding the world of thousands of strategic nuclear war heads.

\section{China's Response to USA after 9/11, 2001.}

From the Chinese perspective September 11 and subsequent global campaign on terror constitute a double-edge sword, presenting both opportunities and challenges. Most officials from the state Council and scholars from civilian Think Tanks hold an optimistic view and see the US wart on terrorism as an opportunity, noting that the US has shifted its attention away from East Asia to central, South and South East Asia.

The September 11 events forced the Bush administration to reassemble its mistrust towards China, chilled by the US surveillance aircraft incident over Hainan in April 2001, and by President Bush's explicit declaration of US willingness to use force to defend Taiwan if necessary and by a generous annual round of US arms sales to Taipei. Following the 9/11 incident, both sides made a fresh start in what is considered as the world's most important bilateral relationship since the end of the cold war. US concerns with the "war on terrorism' took precedence over the concern regarding improvement of relations with China. In the financial sphere, Beijing promised to do its utmost to freeze the assets of terrorist organization and cut off the flow of funds to terrorists. On its parts, the US not only considered lifting some sanctions against China, but also accepted China's concerns in the XinJiang province, a vast desert region bordering Afghanistan, and the crackdown on Uighur separatists. Before the terrorist attacks in the US, the latter had portrayed Chinese crackdown as an abuse of human rights.

\footnotetext{
${ }^{3}$ ibid P. 40

${ }^{4}$ Op-cit P. 41

${ }^{5}$ Mati-ud-Din Kamal Lt.Gen.(R) "Post 9/11 Afghanistan" South Asian Journal P. 116.

${ }^{6}$ Rafique Najam (Autumn 2002) 9/11 a year after appraising US regional strategies strategic studies $\quad$ Vol. 22 Islamabad P. 20 
On the first issue, as far as US-Pakistan anti terrorism cooperation is concerned China may be having some reservation but as a whole China is one of the major party in the anti terrorism war. But the US military in the region needs a withdrawal time table and should limit itself to supporting the counter-terrorism campaign in accordance with its promise to the international community. "Any prolong presence and extended activity of US military forces in the region will only add new unstable factors in South Asia and complicate US relations with China”.

In July 2002, the US imposed sanctions on five Chinese firms exporting missile parts to Iran and Pakistan. On its part, China has also warned the US against using nuclear black male, or the threats of a primitive nuclear strike.

Worries have also suffered over the fate of its nuclear armed ally-Pakistan.

It is notable that the sanction against China on part of exporting missile parts to Pakistan has created the mistrust between the cordial friends. The incident of $9 / 11$ has further reinforced the US urge for uniliteralism. Since September 11, the US has defined terrorism in its own way in a manner as to provide it with a rationale to deploy its military round the globe in the name of so-called war against international terrorism. President Bush has declared Iran, Iraq and North Korea as a part of "axis of evil ". He has declared the Palestinian leader Yasir Arafat (late) a terrorist and asked the Palestinian authority to reform itself.

"A theorist Professor Sameul P Huntington came up with the thesis of a Clash of civilization "of the rest against the west. On the contrary, it was only the American who thought of themselves as the most civilized among all the nations and began intruding in every region of the world to prove their civility." $"$

The incident of 9/11 not only jolted the whole world but also thrust the five Central Asian states on to the center stage as a possible spring board for "US military action against the Taliban and Al-Qaeda in Afghanistan Uzbekistan, Tajikistan and Kazakhstan were quick to offer the US the use of their territories for military operation. This situation was a critical for Pakistan also, because Central Asian states have direct and natural links with China, Afghanistan, Pakistan, Iran and Russia. Central Asian states have not yet played any significant role in the region or in global politics. They, how ever, have ethnic, cultural and historical relation with Afghanistan, and can't ignore developments in this country although the Russia's long term interests here, but its resistance to the US role and influence would be quite natural, and Russia would not like to be expelled from the area where it has its own influence for the last about two hundred years instead of Russia has increased reliance on America for its own economic well being. where as the China's interest in region are very cleared because China's border are common with three Central Asian states, and along with its relations with them China wants to ensure peace here while the other hand America sees in China a big obstacle in way of its interests in the region although, Iran has strong historical and cultural bonds as well as geographic links in the region but since American presence in Afghanistan and Iraq opposes serious problem for Iran, it would naturally look towards establishing more cordial relations with its neighbor and that is the South Asian region, comprises 7 states: India, Pakistan, Bangladesh, Sri-Lanka, Nepal, Bhutan and Maldives. Geography gives India unique positions at the rest of the smaller states are clustered around it. The region accounts for $1 / 5^{\text {th }}$ of the world population but shares only 1.3 percent of the global income. The per capita GNP is $\$ 440$ that is the lowest in the world. The region houses $40 \%$ of the global poverty. In this region the two major states India and Pakistan have bigger land mass, unique geographical position and numerous human resources are the attraction for Western countries as well as USA. Pakistan, is the major regional player, has never accepted Indian hegemony." ${ }^{9}$ The mutual hostility, mistrust and suspicious led the two rivals have engaged in three wars and many low-intensity border conflicts. As tits for tat kinds of mutual relationship led the two major powers of South Asia to go nuclear in May,1998 .the nuclearisation of the region, given the fact that the dispute over Kashmir remains un resolved between India and Pakistan, has made the entire region more unstable and volatile. The other problems of South Asian states are the struggles for the right of self-determination, quest for autonomy revolutionary efforts to reform politico-economic system with in a particular states; ethnic and sectarian conflicts and state terrorism as like "the people of Kashmir fighting the tyranny of Indian military occupation rules Tamil demands for self-ruler autonomy from dominants Sinhalese in Sri-Lanka Maoist rebels fighting to demolish constitutional monarchy in Nepal".

The 9/11 events had a profound impact on security dynamics of South Asia. When the US led collation search for Osama Bin Laden was being conducted in Afghanistan. Pakistan as the neighbor of Afghanistan naturally suffered, especially, when she became a front line state in the war against international terrorism. By getting this chance India tried his best to exploit the US war on terrorism for its own advantages by labeling the

\footnotetext{
${ }^{7}$ Karim Muhammad Khan (Spring 2004) US South Asia policy after 9/11 and its implication, for China National development and security friends journals (quarterly) Vol. 12 Rawalpindi P. 140

${ }^{8}$ Abbas Ahmed "Impact of 9/11 on Smaller States of South Asia", Strategic Studies Vol 22, Islamabad P. 72

${ }^{9}$ ibid P. 75
} 
Kashmiri Mujahideen as terrorists, because, Pakistan had connection with the Taliban government. In this situation the smaller states could not remain isolated from the after shocks of the major developments in the region since 9/11. It affected these states in a multi-dimensional way; impacting the ongoing insurgencies, fight for self determination, efforts for revolutionizing society on their soil, struggles for autonomy, their economies, trade, foreign investment and their perceptions towards India and United States. The detail is given as under country wise impacts after $9 / 11$ on South Asian states.

Nepal.

Nepal is a land locked country situated in the north of India, the events of $9 / 11$ and as a result war against terrorism not only impacted the internal security dynamics of Nepal, but also effected the Indian and American perception and move towards Katmandu. Nepal has been facing a revolt movement lunched by Maoist rebels since 1996. Nepal government rejected the three main demands of the Maoist their demands included abolishing monarchy establishing an interim government and forming a constitutional assembly. "The government of India, which had already become a core ally of the US against its global war on terrorism, began supporting Nepal's effort to deal with the Maoists 'terrorists.' On December 4, 2001, India sent its first arm shipment, guerrilla and jungle war fair and counter-insurgency weapons and surveillance gadgets for the government of Nepal. On May13 2002, the Indian Army Chief visited Nepal and agreed to give military training facilities to the Royal Nepal Army. However, prior to 9/11 India's material and logistic support to Maoists was open secret." 10

Nepal's geographic proximity with China has been a matter with great interest for American policy makers with that interest in mind "the US secretary of states Colin Paul visited Katmandu on January 18 2002, and said during his visit that, there is no room for the use of violence to create political change in democracy, in response laterally Prime Minister of Nepal visited to Washington on May 7 2002, to get US support against the movement of rebels, Maoist. President Bush appreciated Nepal's efforts in countering insurgency and gave Nepal's twenty million US dollars to combat the Maoist terror.",11

After changing this scenario of $9 / 11$ and strong support of both United States and India to the government of Nepal the leadership of Maoists have changed their point of view according to new situation and offered for negotiation with the government on the whole range of issues for joining the main stream politics in the country. Regions such as south Asia directly involved in the war on terrorism were affected both positively and negatively depending on their policies and strategic importance. The impact of 9/11 on the economy of Nepal was almost in significant as it was already in bad shape. The tourism industry was affected by the Maoist unrest and exports were badly hit because of recession in the international market.

\section{Bangladesh.}

Bangladesh is situated at the mouth of Bay of Bengal and India lies to its west and the North East. For the last one decade, successive government in

Dhaka has been trying to put the country's ailing economy on the track. It was on the economic front that Dhaka suffered the most in the wake of 9/11 events. "The down turn in the US economy following the 9/11 events had a serious impact on Bangladesh's trade, foreign direct investment, foreign remittances and oversees employment. In 2001, Dhaka earned \$5 billion from its ready-made governments, of which $\$ 2$ billion arose from exports to the US. As a result of the $9 / 11$ terrorist attacks, there was a wide spread cancellation of orders by the US buyers. Consequently, by mid-October 2001, around half of the 3000 governments factories registered under Bangladesh government manufacturer and exporter Association (BGMEA) had to close down. The oversees job market also shrink after the $9 / 11$ events. The US and many others Western countries tightened their new immigration and visa policies. This created a lot of problems for Bangladesh, where the desire to seek oversees job has always been the peoples preferred choice." 12

The new development came into being after $9 / 11$ and Dhaka had tried to be accommodative in the strategic perceptions of the US of its Western neighbors. The new government in Bangladesh under the leadership of Begum Khalida Zia expressed its full support for the US war on terrorism and its military action in Afghanistan. "On may 19 2002, Khalida Zia sent her Foreign Minister Morshed Khan to Washington, to high light Bangladesh's credentials as an important ally of the US in its war against terrorism." 13

\section{Sri-Lanka.}

The island country of Sri-Lanka, situated to the South of India, has been facing ethnic conflict since 1983. The Tamil community, which constitutes $14 \%$ of countries population is fighting for its independent self-

\footnotetext{
${ }^{10}$ ibid P. 78

${ }^{11}$ Op-cit P. 79

12 ibid P. 80

${ }^{13}$ Op-cit P. 81
} 
rule in the North and Western part of Sri-Lanka. a significant term in the Tamil terrorist activities came about when the US government on October 11 2001, included The Liberation Tiger of Tamil Elam (LTTE) in its list of terrorist organizations. "Realizing the changed global scenario after 9/11 the newly elected government under the leadership of Prime Minister, Ranil Wickremesinghe, grabbed the new opportunity for peace and soon after assuming power in December 2001, invited The Liberation of Tiger Tamil Elam (LTTE) for peace negotiation. In a memorandum of understanding was signed between the Sri Lanka government and the 'LTTE' on February23 2002, laying down the modalities of a peace accord. On the one hand Sri-Lankan Prime Minister visited Washington on July23 2002, and earned appreciation and support from the US President, George Bush, for the on going peace process. While on the other hand, the Sri-Lankan Prime minister also visited India from June 8-11 2002, to boost bi-lateral economic ties. Indian attitude towards Colombo has never been so cordial ever before" ${ }^{14}$

\section{Bhutan.}

The Kingdom of Bhutan is another land locked country situated towards the North East of India it is relatively stable country, having been kept out of colonial domination, cold war and regional revelries. The impact of $9 / 11$ on the internal and external security dynamics of Bhutan was only marginal. There are two primary security concerns for Bhutan one illicit incursions by the United Liberation Front of Assam (ULFA) and by the national democratic front for bodoland (NDFC) in the Southern Bhutanese jungle. Of the two afore said security concern the 'ULFA' problem has been the major irritant in India-Bhutan bi-lateral relations since 1991. The two rebel forces had been establish their camps in the Southern jungle of Bhutan to create the unrest in the country but "after $9 / 11$ there seems to be realization among the 'ULFA' cadres that they could not go much further with there maneuvers. Therefore by the first week of December 2001, 'ULFA' had begun to implement the agreement by winding up its first camp. Such agreement was signed in June 2001, with the government of Bhutan to vacate and close four of their nine camps." 15

Regions such as South Asia, directly involved in the war on terrorism, were affected both positively and negatively depending on their policies and strategic importance where as concern the positive aspects. India is one of the fastest growing economies of the world. Its vast geographical extent, long costal line, enormous human resource potential, rising IT and software industry and expanding trade can be immense benefit for the smaller states of the region. If India ideally behaves like a sensible big brother. It could go a long way in fostering regional prosperity and development. Because South Asia is called a flash point due to both India and Pakistan have acquired a nuclear capability. Given their long-standing hostility, an error of judgment, an accident, or desperate brink man ship by one or the other side could lead a nuclear confrontation. Therefore, to nuclear capable states can not afford to be reckless and allow their confrontation go beyond a certain limit has been blessing in disguise which according to some critics has offset the perils of going nuclear for a developing nation. So, the extension in the Indo-Nepal trade treaty for another five years is a positive step as would allow Nepali product a duty free access to Indian markets. Similarly India can benefit from a numerous natural gas reserves of Bangladesh and the later could ask fore a duty-free access of its products to the Indian market. The trend of closer regional ties, particularly closer co-operation in economic and trade field is fast emerging in the changing international situation. The nation living in the different part of the world are enhancing their relations with their neighbors in a way in which they not only learn from one another's experiences but where benefits of economic development con also be transferred and result in over all regional development. European Union is a significant example in this regard. Similarly, the increasing cooperation between South East Asian countries from the forum of Association of South East Asian Nations (ASEAN) is bringing stability and prosperity in that region. India could play a more positive role for regional cooperation through the SAARC forum by enhancing cooperation among the SAARC states. "In the past because of ideological, economic and strategic reason major parts of Asia have been locked in a strategic struggle and maneuvering of trade and business. Now as it is predicted by economic Pundits that $21^{\text {st }}$ century will be dominated by Asia and as the traditional Asia is under going major transformation with China being hail as the power house for growth in Asia- a role once played by Japan- a new information technology giant in the shape of India, with rapid industrialization, new attractive patterns of investment and rationalization of economy in the shape of ASEAN and SAARC and the slogans for Asian currency are directly or indirectly helping major parts of mainstream Asia to get closer and closer."16

For this purpose, in the recent $13^{\text {th }}$ SAARC summit held in Dhaka Pakistan, purposed to China for the member as observer in such summit to strengthen this forum although, India has opposed this suggestion and china have also reservation over the presence of Nieto Forces in this region, and the steady improvement of Indo-US relation in the 90's and the Bush Vajpai proclamation of a strategic partnership in November 2001,

\footnotetext{
${ }^{14}$ ibid PP.82 83

${ }^{15}$ ibid. P. 84

${ }^{16}$ Ramzan Ali Muhammad (Autumn 2004) China-South Asia Relations in a changing world, Regional Studies Quarterly journal Vol. 22, No. 4 Islamabad, P. 84
} 
helped a lot enhancing American's regional role. Where as concerned the negative aspects of $9 / 11 \mathrm{n}$ this region is to be a ganging up of the US Israel and India in the ongoing war against international terrorism. Any state oppression by these close allies of the US will be considered legitimate, and the voice of the suppressed will be branded as terrorism. Further more, the preponderance of India in the regional affairs would give it a free hand in South Asia to act uni-laterally in the style of US, where ever and when ever it wants as Mr. Bush said "the expanded cooperation is an extended mile stone in transforming the relationship between US and India based increasingly on common values and common interests. Also Mr. Bush's statement that a partner ship with India would increase stability in Asia was an acknowledgement that India has assumed a significant position in US strategic and security plan in Asia." 17

In this scenario the Indian brinkmanship to force Pakistan to accept the responsibility of alleged cross border terrorism is one such example of how a powerful India would act as the uni-lateral power in region. The ultimately result would be an India becoming a big bully instead of a big brother. The SAARC regional forum must be strengthen to solve the problems among the states through bi-lateral dialogue, "but unfortunately in SAARC there is an inherent fear of the domination of one state, which is larger than the combine strength of all the other states. Secondly there are economic and political conflicts among the states. The South Asian free trade agreement scheduled to come into force from January $1^{\text {st }}$, 2006, may not be implemented, as it is link to substantive progress in peace talks between India and Pakistan. In the other words, SAARC's future hinges, to a large extent, on the satisfactory settlement of the Kashmir dispute."

\section{US Relations with India is a threat to smaller states of South Asia.}

In South Asia, India's size its vast market industrial infra structure and economic potential as compared to the smaller nations of the region, would ensure her privacy today in US multi national plans, and hence in US foreign policy. The pro-Indian policy that began in the last years of the Clinton administration is getting a further boost with the Bush administrations, therefore, "During the recent visit to the New Delhi, the US under secretary of state, Nicholas burns, assured his hosts that the US was fully committed to implementing the Nuclear deal with India addressing a joint press conference with the Indian foreign secretary Shayan Saran, on October 21, 2005, Mr. Burns stressed that the United States saw India as 'great power' which would work with it in promoting 'peace and stability' in the world."19

In the above said situation it can be judged that US is taking keen interest to enhance its relations with India, which would create the implications for China that is the reliable and best friend of Pakistan. In the short span of seven years, US foreign policy towards Asia particularly South Asia, has undergone. In 1998 during his China visits, US President Bill Clinton publicly conceded that Beijing has illegitimate interests in South Asia but now the US Sino-relations deteriorating fairly rapidly having an economic alternative in India gives the US leverage with China on the host of issues. If the history of the past 50 years is of any relevance it shows that the South Asia giant a seen by its smaller neighbors as a threat rather than as a protector against other predators. Whenever New Delhi adds a new device to its military muscle, its smaller Neighbors watch with a high degree of nervousness as most of them have experienced, in one way or another, India's regional hegemonic aspirations. It is unfortunately that rise of India as a great power in South Asia with American support is likely to have a bad effect not only upon its Neighbors but also the regional states of the Indian Oceans, that is the main hurdle so solving the problems by meaningful dialogues among states of South Asia.

\footnotetext{
${ }^{17}$ Mahmood Afzal (Dec. 2004) New Phase in Pak-US ties the Dawn Karachi Saturday December 112004

${ }^{18}$ Noor-ul-Haq Dr. Saarc's furture hinges on Kashmir The Dawn Vol Lix No. 337 Lahore10 ${ }^{\text {th }}$ December 2005.

${ }^{19}$ Mehmood Afzal Indo-US Nuclear alliance The Dawn Vol No. IX no. 297 dated October 29, 2005.
} 